\title{
Zinc Finger Protein DPF3
}

National Cancer Institute

\section{Source}

National Cancer Institute. Zinc Finger Protein DPF3. NCI Thesaurus. Code C157312.

Zinc finger protein DPF3 (378 aa, $\sim 43 \mathrm{kDa}$ ) is encoded by the human DPF3 gene. This protein is involved in neuron-specific chromatin remodeling. 